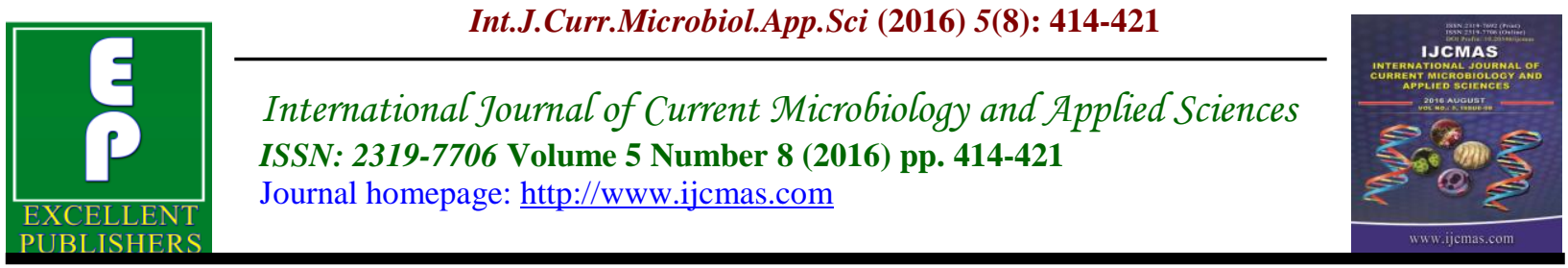

Original Research Article

http://dx.doi.org/10.20546/ijcmas.2016.508.044

\title{
In Vitro Cytotoxicity Effect of Kaempferol in Breast Cancer Cell Lines MCF-7 and Lung Cancer Cell Lines A459
}

\author{
Ramesh L. Londonkar* and Basavarajeshwari S. Awanti \\ Dept of Biotechnology, Gulbarga University, Gulbarga-585105 Karnataka, India \\ *Corresponding author
}

\begin{tabular}{|c|c|}
\hline & A B S T R A C T \\
\hline $\begin{array}{l}\text { Ke y w o r d s } \\
\text { Kaempferol, } \\
\text { cytotoxicity effect, } \\
\text { breast cancer, } \\
\text { lung cancer. }\end{array}$ & \multirow{3}{*}{$\begin{array}{l}\text { In this study cytotoxic effect of kaempferol isolated from Vigna unguiculata was } \\
\text { evaluated on breast cancer (MCF-7) and lung cancer A } 459 \text { cell lines. MCF- } 7 \text { and } \\
\text { A459 cells were cultured in DMEM medium and incubated with different } \\
\text { concentrations }(100,50,25,12.5,6.25 \mu \mathrm{g} / \mathrm{ml}) \text { of kaempferol .The cell viability } \\
\text { was assessed by MTT assay. Kaempferol has decreased malignant cells in a } \\
\text { concentration dependent manner. The IC50 values in MCF-7 and A459 cells were } \\
\text { determined as } 90.28 \pm 4.2 \mu \mathrm{g} / \mathrm{ml} \text { and } 35.80 \pm 0.4 \mu \mathrm{g} / \mathrm{ml} \text { respectively. It may be } \\
\text { concluded that kaempferol can cause cell death in MCF-7 and A459 cancer cells } \\
\text { which is considered as a promising chemotherapeutic agent in breast cancer and } \\
\text { lung cancer treatment. }\end{array}$} \\
\hline Article Info & \\
\hline $\begin{array}{l}\text { Accepted: } \\
21 \text { July } 2016 \\
\text { Available Online: } \\
10 \text { August } 2016\end{array}$ & \\
\hline
\end{tabular}

\section{Introduction}

Cancer has been thought to be a preventable disease due to its slow development and progression, taking many years to become invasive in a step by- step manner (Sreejaya and Santhy, 2013). Such property provides a greater opportunity not only for early detection, but a particular interest in the role of medicinal plant extracts in cancer prevention. Plants are the rich sources of chemically diverse compounds, many with beneficial properties to human health. Consequently, about $50 \%$ of the anticancer therapeutic agents known are derived from plants (Balunas and Kinghorn, 2005).
Institute has screened about 35,000 higher plant species for activity against cancer, where about 3,000 of these plants have demonstrated reproducible activity. As mentioned above, the exploration of nature as a source of new active agents is needed for discovering bioactive chemo- types from natural product for the development and novel molecular diversity of efficacious drugs. In this respect, natural products from plants, used either alone or with combinatorial synthetic methodologies, constitute a multidisciplinary approach to the current drug productivity (Newman et al., 2003) (Cos et al., 2006). 
Breast cancer is one of the most aggressive types of cancer that can occur in women of any age and is the most frequently diagnosed cancer in women worldwide and ranks second as a cause of cancer death (Am. Can. Soc., 2012). A number of dietary factors have been linked to the risk for breast cancer. Dietary factors which may increase risk include a high fat diet (Blackburn, 2007).

Lung cancer is the uncontrolled growth of abnormal cells in one or both of the lungs. Cigarette smoking causes most lung cancers when smoke gets in the lungs. Lung cancer kills 1.3 million people each year, more than any other cancer. It is currently the leading cause of cancer death in both men and women, cancer has been regarded as a leading cause of cancer related mortality throughout the world .Its occurrence and development are associated with a variety of factors disorders, dysfunction of lung epithelial cells, inflammation etc (Carpagnano et al., 2011). Lung cancer is the most common cancer worldwide and accounts for $75-80 \%$ death. The current chemotherapy treatment method will destroy the normal cells along with cancer cells and also sometime develops resistance to treatment. So, the discovery of novel drugs of natural origin which are less toxic, endowed with fewer side effects and more potent in their mechanism of action are necessary to be discovered (Sumathy Arockiasamy and Vinu Ramachandran, 2012).

According to World Health Organization, 80 $\%$ of the people living in rural areas depend on medicinal herb as primary healthcare system, The herbal formulations can be designed to attack the cancerous cells without harming normal cells of the body. Herbal medicines have a vital role in the prevention and treatment of cancer. Cancer can be defined as a disease in which a group of abnormal cells grow uncontrollably by disregarding the normal rules of cell division. It is serious, frightening diseases about a third of humans develop cancer in a lifetime (Marcy et al., 2005) (Minky Mukhija et al., 2015). It is caused by both external factors (tobacco, chemicals, radiation and infectious organisms) and internal factors (inherited mutations, hormones, immune conditions and mutations). Treatment for cancer includes local treatments, such as radiation therapy, surgery and systemic treatments such as chemotherapy and targeted therapy. Despite considerable progress in the management of cancer by conventional synthetic drugs, the search for natural anti-cancer plant products for controlling cancer is very important as synthetic drugs has many side effects (Michael Marmot, 2007). Today much attention has been devoted to natural antioxidant and their association with health benefits. Plants are the potential source of natural antioxidants. Reactive oxygen species (ROS) are generated as byproducts of biological reactions and from exogenous factors (Wiseman, 1996). Excess ROS, if not eliminated by antioxidant system, results in high levels of free radicals which causes oxidative stress (Sreeramulu et al., 2013). Oxidative stress arising from free radicals is the basis of many diseases such as cancer (Reuter et al., 2010) (Durackova, 2010). The curative effects of several medicinal plants are usually due to antioxidant phytochemicals present in it such as polyphenols, flavonoids and phenolic compounds (Yildrim et al., 2001).

Recently flavanoids have attracted considerable interest because of their potential beneficial effects on human health. They have been reported to have antiviral, anti-allergic, antiplatelet, anti-inflammatory, antitumor, antioxidant, antithrombotic, hypolipidemic and hypoglycemic activities (Joby jose et al., 2014). 
Materials and Methods

\section{Chemicals \& reagents}

3-(4,5-dimethyl thiazol-2-yl)-5-diphenyl tetrazolium bromide (MTT), Fetal Bovine serum (FBS), Phosphate Buffered Saline (PBS), Minimum Essential Medium (MEM) and Trypsin were obtained from Sigma Aldrich Co, St Louis, USA. EDTA, Glucose and antibiotics from Hi-Media Laboratories Ltd., Mumbai. Dimethyl Sulfoxide (DMSO) and Propanol from E.Merck Ltd., Mumbai, India.

\section{Cell lines and culture medium}

MCF-7(Human Breast Carcinoma) \& A549 (Human Lung Carcinoma) cell lines were procured from National Centre for Cell Sciences (NCCS), Pune, India. Stock cells were cultured in MEM supplemented with $10 \%$ inactivated Fetal Bovine Serum (FBS), penicillin (100 IU/ml), streptomycin (100 $\mu \mathrm{g} / \mathrm{ml})$ and amphotericin B $(5 \mu \mathrm{g} / \mathrm{ml})$ in an humidified atmosphere of $5 \% \mathrm{CO}_{2}$ at $37^{\circ} \mathrm{C}$ until confluent. The cells were dissociated with TPVG solution $(0.2 \%$ trypsin, $0.02 \%$ EDTA, $0.05 \%$ glucose in PBS). The stock cultures were grown in $25 \mathrm{~cm}^{2}$ culture flasks and all experiments were carried out in 96 microtitre plates (Tarsons India Pvt. Ltd., Kolkata, India). flavonoid constituents Minky Mukhija, Mahendra Pal Singh, Kanaya Lal Dhar,

\section{Preparation of Test Solutions}

For Cytotoxicity studies, the weighed test drug was separately dissolved in distilled DMSO and volume was made up with MEM supplemented with $2 \%$ inactivated FBS to obtain a stock solution of $1 \mathrm{mg} / \mathrm{ml}$ concentration and sterilized by filtration. Serial two fold dilutions were prepared from this for carrying out cytotoxic studies.
Determination of cell viability by MTT Assay

The ability of the cells to survive a toxic insult has been the basis of most Cytotoxicity assays. This assay is based on the assumption that dead cells or their products do not reduce tetrazolium. The assay depends both on the number of cells present and on the mitochondrial activity per cell. The principle involved is the cleavage of tetrazolium salt 3-(4, 5 dimethyl thiazole2-yl)-2, 5-diphenyl tetrazolium bromide (MTT) into a blue coloured product (formazan) by mitochondrial enzyme succinate dehydrogenase. The numbers of cells were found to be proportional to the extent of formazan production by the cells used.

The monolayer cell culture was trypsinized and the cell count are adjusted to $1.0 \times 10^{5}$ cells/ml using MEM containing 10\% FBS. To each well of the 96 well microtitre plate, $0.1 \mathrm{ml}$ of the diluted cell suspension (approximately 10,000 cells) was added. After $24 \mathrm{~h}$, when a partial monolayer was formed, the supernatant was flicked off, washed the monolayer once with medium and $100 \mu \mathrm{l}$ of different concentrations of test drug were added on to the partial monolayer in microtitre plates. The plates were then incubated at $37^{\circ} \mathrm{C}$ for 3 days in $5 \% \mathrm{CO}_{2}$ atmosphere, and microscopic examination was carried out and observations were noted every $24 \mathrm{~h}$ interval. After $72 \mathrm{~h}$, the drug solutions in the wells were discarded and 50 $\mu \mathrm{l}$ of MTT in PBS was added to each well. The plates were gently shaken and incubated for $3 \mathrm{~h}$ at $37^{\circ} \mathrm{C}$ in $5 \% \mathrm{CO}_{2}$ atmosphere. The supernatant was removed and $100 \mu \mathrm{l}$ of propanol was added and the plates were gently shaken to solubilize the formed formazan. The absorbance was measured using a microplate reader at a wavelength of $540 \mathrm{~nm}$. The percentage growth inhibition 
was calculated using the following formula and concentration of test drug needed to inhibit cell growth by $50 \%\left(\mathrm{CTC}_{50}\right)$ values is generated from the dose-response curves for each cell line (Francis, 1986).

$\%$ Growth Inhibition $=100-$

$\left(\frac{\text { Mean OD of individual test group }}{\text { Mean OD of control group }} \times 100\right)$

\section{Results and discussion}

Cancer is a dreadful disease across the worldwide, and the treatment strategies for combating cancer severity have gained more importance to public health. For the development of new anticancer drugs, drug combinations, and chemotherapy strategies by methodical and scientific exploration of the enormous pool of synthetic, biological, and natural products. Cancer chemopreventions with strategies using foods and medicinal herbs have been considered as the main strategy in cancer control (Vennila srinivasahan, 2015).

In conclusion, the plant vigna unguiculata seeds of methanolic extract of bioactive compound kaempferol in vitro investigated against MCF-7 and A459 -cell lines, and resulted with $\mathrm{IC} 50=90.28 \pm 4.2,35.80 \pm 0.4$ $\mu \mathrm{g} / \mathrm{ml}$ respectively. This may be due to the presence of flavonoid compound especially kaempferol which also show high cytotoxicity which isolated from high polar fraction of the methanolic extract, in we study the cytotoxicity of MCF-7,A459 cell lines by isolated compound. Our findings are line line with previous studies (Nguyen et al., 2003).

Table.1 Cytotoxic property of test drug against MCF-7 cell line

\begin{tabular}{|l|l|l|l|l|}
\hline Sl. No & $\begin{array}{l}\text { Name of } \\
\text { Test sample }\end{array}$ & $\begin{array}{l}\text { Test Conc. } \\
(\boldsymbol{\mu g} / \mathbf{m l})\end{array}$ & \% Cytotoxicity & $\begin{array}{l}\mathbf{C T C}_{\mathbf{5 0}} \\
(\boldsymbol{\mu g} / \mathbf{m l})\end{array}$ \\
\hline & & 100 & $52.32 \pm 1.1$ & \\
& & 50 & $40.58 \pm 0.8$ & \\
$\mathbf{1}$ & RR $\mathbf{2 8 5 2}$ & 25 & $36.21 \pm 2.4$ & $90.28 \pm 4.2$ \\
& & 12.5 & $31.73 \pm 0.8$ & \\
& & 6.25 & $22.31 \pm 4.4$ & \\
\hline
\end{tabular}

Table.2 Cytotoxic property of test drug against A549 cell line

\begin{tabular}{|l|l|l|l|l|}
\hline Sl. No & $\begin{array}{l}\text { Name of } \\
\text { Test sample }\end{array}$ & $\begin{array}{l}\text { Test Conc. } \\
(\boldsymbol{\mu} \text { g/ml) }\end{array}$ & \% Cytotoxicity & $\begin{array}{l}\mathbf{C T C}_{\mathbf{5 0}} \\
(\boldsymbol{\mu g} / \mathbf{m l})\end{array}$ \\
\hline & & 100 & $83.72 \pm 1.1$ & \\
& & 50 & $71.15 \pm 0.8$ & \\
$\mathbf{1}$ & RR 2852 & 25 & $33.87 \pm 1.6$ & $35.80 \pm 0.4$ \\
& & 12.5 & $10.15 \pm 0.8$ & \\
& & 6.25 & $0.99 \pm 0.6$ & \\
\hline
\end{tabular}


Fig.1 Cytotoxic effect of the sample RR 2852 on MCF-7 cell line

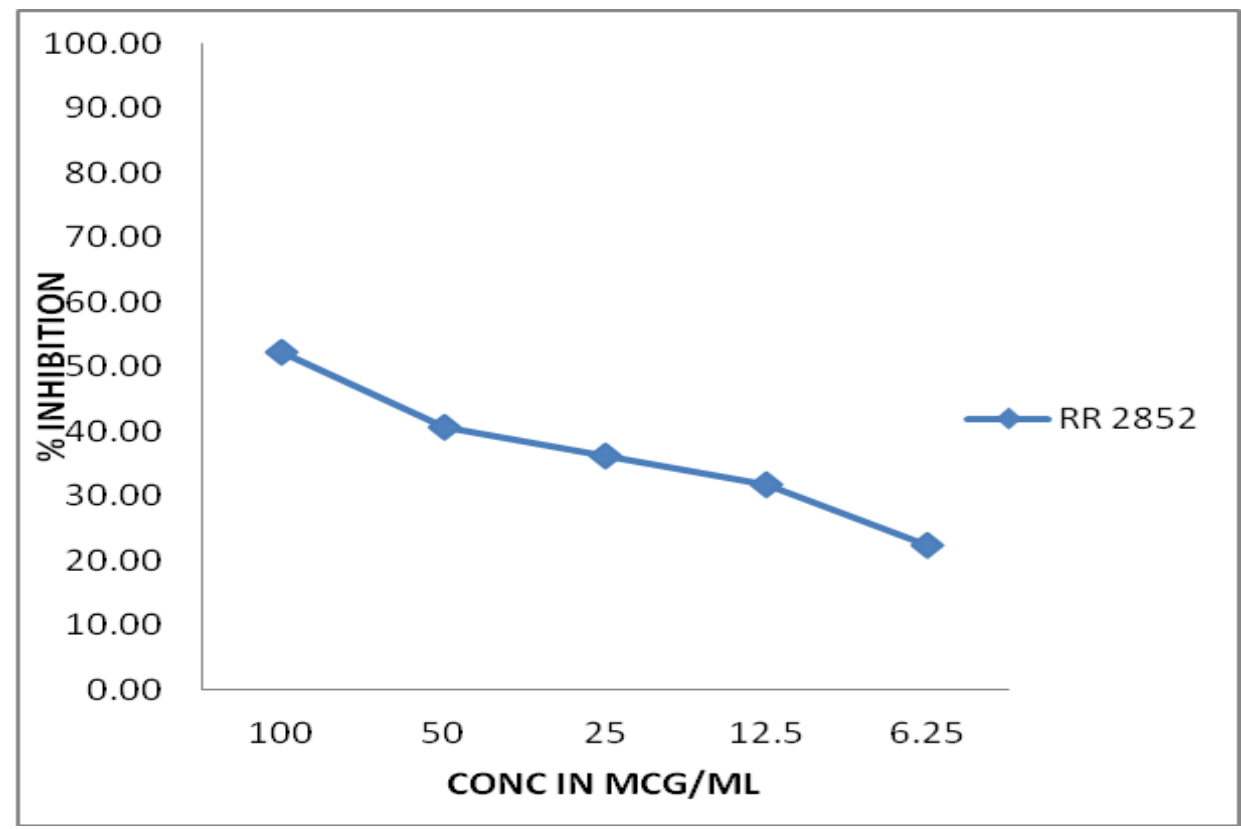

Fig.2 Cytotoxic effect of the sample RR 2852 on A549 cell line

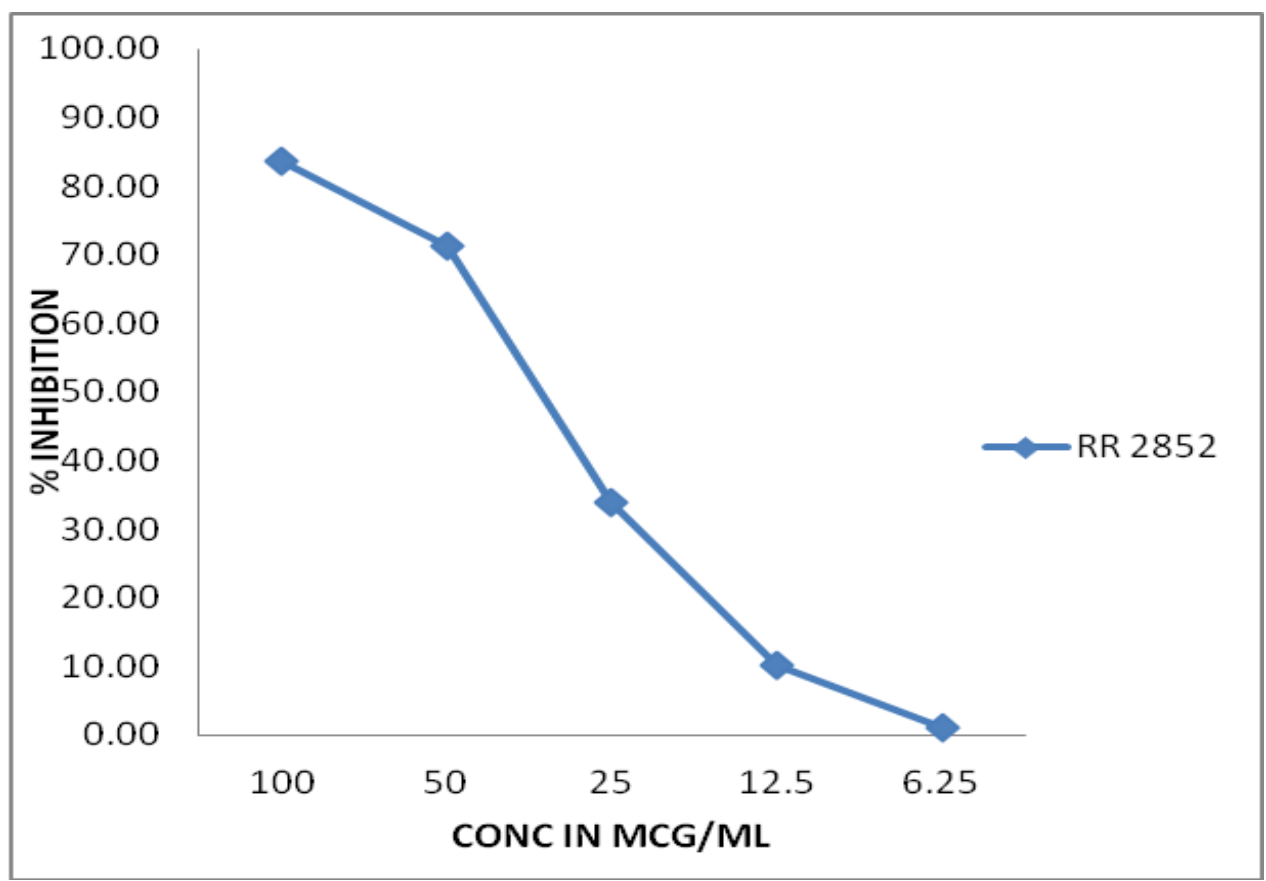


Fig.3 Photos

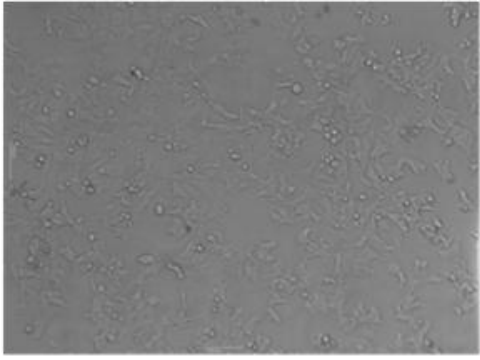

MCF-7 (CONTROL)

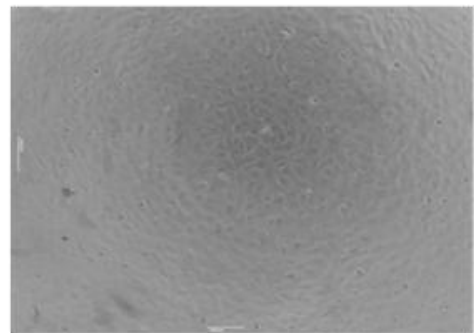

A549 (CONTROL)

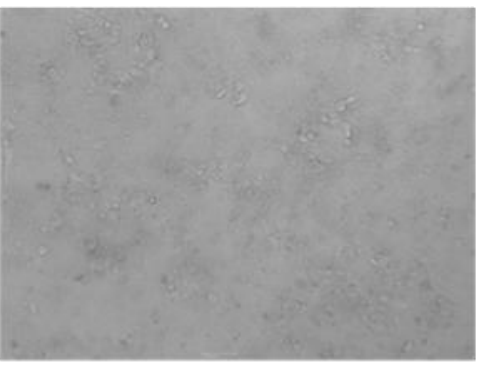

MCF-7 RR $2852(100 \mu \mathrm{g} / \mathrm{ml})$

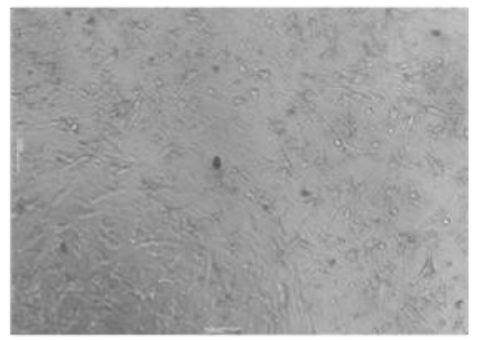

A549 RR $2852(100 \mu \mathrm{g} / \mathrm{ml})$

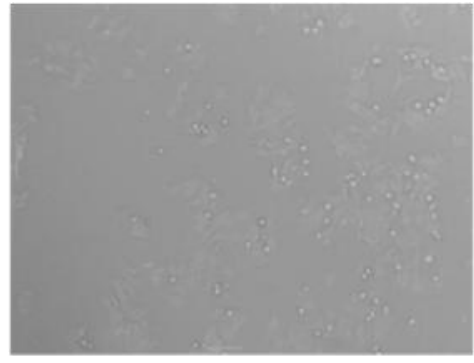

MCF-7 RR $2852(50 \mu \mathrm{g} / \mathrm{ml})$

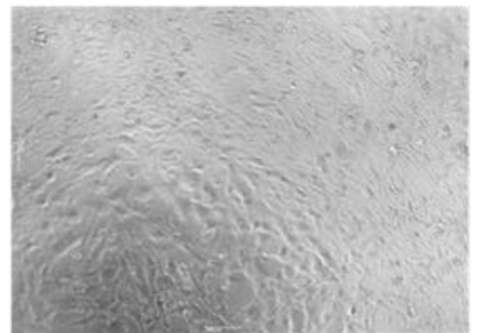

A549 RR $2852(50 \mu \mathrm{g} / \mathrm{ml})$
Kaempferol is a polyphenol antioxidant found in fruits and vegetables. Many studies have described the beneficial effects of dietary kaempferol in reducing the risk of chronic diseases, especially cancer. . Not only the kaempferol is a potent promoter of apoptosis (Ramos, 2007), but it also modifies a host of cellular signaling pathways. In addition, kaempferol is much less toxic to normal cells in comparison to standard chemotherapy drugs (Allen et al., 2013).

In the present time herbal products are considered to be symbols of protection of cells in comparison to the synthetic product that are regarded as unsafe to human life and environment. Although herbs have been priced for their medicinal importance. But now everyday phytochemical and pharmacological studies are conducted on different parts of plants. Several mechanisms of action were detected in
MCF-7 cells and A459 cells. In the present study, isolated compound from methanolic extract of vigna unguiculata was found to be cytotoxic towards human MCF-7 and A 459 in MTT assay and the concentration required for $50 \%$ cell death was found to be $90.28 \mathrm{~g} \pm$ $4.2 \mu \mathrm{g} / \mathrm{ml}$ and $35.80 \pm 0.4 \mu \mathrm{g} / \mathrm{ml}$. Hence present study shows the efficacy of kaempferol for the cytotoxicity towards MCF-7 cells and A459 cells are highly significant (Blackburn, 2007).

Medicinal plants are able to act through several mechanisms to provide protection against cancer. The percentage of cytotoxicity to MCF-7 cells and A459 cells which are exposed to the kaempferol to wide concentrations at 100, 50, 25, 12.5, 6.25 $\mu \mathrm{g} / \mathrm{ml}$ was found to be $52.32 \pm 1.1$, $40.58 \pm 0.8, \quad 36.21 \pm 2.4, \quad 31.73 \pm 0.8$, $22.31 \pm 4.4$, and 83.72 $\pm 1.1,71.15 \pm 0.8$, $33.87 \pm 1.6,10.15 \pm 0.80 .99 \pm 0.6$ respectively. The dose-dependent anti-proliferative effect 
on the cell viability of MCF-7 and A459was observed. The results have been summarized in Table 1 and 2 . Inhibitory concentration 50 (IC50) of MCF 7 is $90.28 \pm 4.2 \mu \mathrm{g} / \mathrm{ml}$ and A459 is $35.80 \pm 0.4 \mu \mathrm{g} / \mathrm{ml}$ value indicated that the maximum cytotoxic effect ofkaempferol which is a isolated fraction of vigna unguiculata showed $50 \%$ reduction in cell viability upon treatment with highest concentration.

Thus it can be concluded that the kaempferol is acting as an anticancerous agent to kill the MCF-7 and A-459 cells without harming the normal cells .hence this can be for mutated as a new anticancer drug.

\section{References}

Allen, Y., Chen, Yi Charlie Chen. 2013. A review of the dietary flavonoid, kaempferol on human health and cancer chemoprevention. Food Chem., 138(4): 2099-2017.

Am. Can. Soc. Cancer Facts and Figures 2012.

Balunas, M.J., Kinghorn, A.D. 2005. Drug discovery from medicinal plants. Life Sci., 78(5): 431-441.

Blackburn, G.L., Wang, K.A. 2007. Dietary fat reduction and breast cancer outcome: results from the Women's Intervention Nutrition Study (WINS). The American J. Clin. Nutri., 86(3): s878-81.

Blackburn, G.L., Wang, K.A. 2007. Dietary fat reduction and breast cancer outcome: results from the Women's Intervention Nutrition Study (WINS). The American J. Clin. Nutri., 86(3): s878-81.

Carpagnano, G.E., Palladino, G.P., Lacedonia, D., Koutelou, A., Orlando, S., Foschino-Barbaro, M.P. 2011. Neutrophilic airways inflammation in lung cancer: The role of exhaled LTB4 and IL-8. BMC Cancer, 7: 226.
Cos, P., Vlietinck, A.J., Berghe, D.V., Maes, L. 2006. Anti-infective potential of natural products: How to develop a stronger in vitro 'proof-of-concept'. $J$. Ethnopharmacol., 106(3): p. 290- 302.

Durackova, Z. 2010. Some Current Insights into Oxidative Stress. Physiol. Res., 59(4): 459-469.

Francis, D., Rita, L. 1986. Rapid "colorometric assay for cell growth and survival modifications to the tetrazolium dye procedure giving improved sensitivity and reliability". $J$. Immunol. Methods, 89: 271-277.

Joby jose, Sudheesh Sudhakaran, Sumesh Kumar, T.M., Sony Jayaraman, Jayadevi, Variyar. 2014. A comparative evaluation of anticancer activities of flavonoids isolated from mimosa pudica, aloe vera and phyllanthus niruri against human breast carcinoma cell line (mcf-7) using $\mathrm{mtt}$ assay. Int. J. Pharmacy and Pharma. Sci., 6(2): 319-322.

Marcy, J., Balunas, A,. Douglas Kinghorn, B. 2005. Drug discovery from medicinal plants. Life Sci., 78: 431 441.

Michael Marmot. 2007. American Institute for Cancer Research. Food, Nutrition, Physical Activity, and the Prevention of Cancer: a Global Perspective. Washington DC.

Minky Mukhija, Mahendra Pal Singh, Kanaya Lal Dhar, Ajudhia Nath Kalia. 2015. Cytotoxic and antioxidant activity of Zanthoxylum alatum stem bark and its flavonoid constituents. $J$. Pharmacognosy and Phytochem., 4(4): 86-92.

Newman, D.J., Cragg, G.M., Snader, K.M. 2003. Natural products as sources of new drugs over the period 1981-2002. J. Natural Products, 66(7): 1022-1037.

Nguyen, T.T., Tran, E., Ong, C.K., Lee, S.K., Do, P.T., Huynh, T.T., Nguyen, 
T.H., Lee, $\quad$ J.J., Tan, $\quad$ Y., Ong, C.S., Huynh, H. 2003. Kaempferolinduced growth inhibition and apoptosis in A549 lung cancer cells is mediated by activation of MEKMAPK. J. Cell Physiol., 197(1): 11021.

Reuter, S., Gupta, S.C., Chaturvedi, M.M., Aggarwal, B.B. 2010. Oxidative Stress, Inflammation, and Cancer: How are They Linked? Free Radical Biol. Med., 9(11): 1603-1616.

Sreejaya, S.B., K.S. Santhy. 2013. Cytotoxic properties of Acorus calamus in MCF 7 breast cancer cells. Int. Curr. Res. Aca. Rev., 1(1): 106-111.

Sreeramulu, D., Reddy, C.V.K., Chauhan, A., Balakrishna, N., Raghunath, M. 2013. Natural Antioxidant Activity of Commonly Consumed Plant Foods in India: Effect of Domestic Processing. Oxidative Medicine Cellular Longevity, $1-12$.
Sumathy Arockiasamy, Vinu Ramachandran, Kalaivani, M., Kuppuswamy. 2012. Antiproliferative activity of methanolic fruit extract of Pedalium murex Linn against Lung Cancer Cell Line A549. J. Pharm. Res., 5(5): 2861-2866.

Vennila srinivasahan, Brindha Durairaj. 2015. In vitro cytotoxic and apoptotic activity of polysaccharide rich morinda citrofolia fruit on mcf-7 cells. Asian J. Pharmaceutical and Clin. Res., 8(2): 190-193.

Wiseman, H., Halliwell, B. 1996. Damage to DNA by reactive oxygen and nitrogen species: Role in inflammatory disease and progression to cancer. Biochem. J., 313(1): 17-29.

Yildrim, A., Oktay, M., Bilaloglu, V. 2001. The antioxidant activity of leaves of Cydonia vulgaris. Turkish J. Med. Sci., 31: 23-27.

\section{How to cite this article:}

Ramesh L. Londonkar and Basavarajeshwari S. Awanti. 2016. In Vitro Cytotoxicity Effect of Kaempferol in Breast Cancer Cell Lines MCF-7 and Lung Cancer Cell Lines A459. Int.J.Curr.Microbiol.App.Sci. 5(8): 414-421. doi: http://dx.doi.org/10.20546/ijcmas.2016.508.044 